\title{
Should a Military Base Be Established in TRNC?
}

\author{
Yurdagül Atun'1, Ata Atun1, Elnur Hasan Mikail2, Selman Arslanbaş¹, Ayman Köle1 \\ ${ }^{1}$ Cyprus Science University, Girne, TRNC \\ ${ }^{2}$ Department of International Relations, Faculty of Economics and Business Administration, Kars Kafkas University, \\ Kars, Turkey \\ Email: yurdagulatun@csu.edu.tr, ataatun@csu.edu.tr, emikail@turansam.org, selmanarslanbas@csu.edu.tr, \\ aymankole@csu.edu.tr
}

How to cite this paper: Atun, Y., Atun, A., Mikail, E. H., Arslanbaş, S., \& Köle, A. (2019). Should a Military Base Be Established in TRNC? Open Journal of Political Science, 9, 502-511.

https://doi.org/10.4236/ojps.2019.93028

Received: May 7, 2019

Accepted: June 9, 2019

Published: June 12, 2019

Copyright $\odot 2019$ by author(s) and Scientific Research Publishing Inc. This work is licensed under the Creative Commons Attribution International License (CC BY 4.0).

http://creativecommons.org/licenses/by/4.0/

\begin{abstract}
The aim of this article is to examine the existing military balance of power on the island and whether Turkey, as one of the guarantors of the 1960 Cyprus Republic, would need to establish a military base on the island due to the hydrocarbon-derived crisis taking place in the Eastern Mediterranean and the special military agreements unilaterally signed by Greek Cypriot Administration (GCA) with other countries against Turkey and Turkish Republic of Northern Cyprus (TRNC). The scope of this article is to elaborate the military bases and forces on the island, the military agreements signed by the both parties, Greek Cypriots and Turkish Cypriots, the balance of power of each side, effects of the hydrocarbon resources within the Exclusive Economic Zones (EEZ) of Turkey, TRNC and GCA, the international crisis on the verge to arise from the overlapping EEZ's of Turkey, TRNC and GCA and the military co-operation need of TRNC with Turkey, to withstand the possible military threats of GCA and allies. The major findings on the issue reveal a unique military structure in the island never seen in the history of the world before. According to the 1960 Constitution of the Republic of Cyprus, announced on 16 August 1960, there exists three different military forces on the Cyprus island. First one is the British Sovereign bases consisted of Akrotiri and Dhekelia. The second one is the Greek Regiment of 950 personnel and the third is the Turkish Regiment of 650 personnel. In addition to these, there is the Greek National Guard Army, which has approximately 120,000 personnel where 80 percent of the officers of the Greek Cypriot National Guards are officers from the Greek Armed Forces of Greece. The Turkish Cypriot Security Forces of 5000 personnel and the Turkish Peace Force of 24,000. And there is the United Nations Force in Cyprus (UNFICYP) as an unbiased,
\end{abstract}


neutral military force. The Greek Cypriot Administration (GCA) is continuing its activities starting from 1963 to bring its presence on the island to the point of ownership and to take over the entire island of Cyprus. At the beginning of the twentieth century, with the encouragement and support of the powerful European States, the Greeks stepped on the shores of Anatolia on May 15, 1919, in order to seize the whole of Western Anatolia and reestablish the "Great Hellen Empire". With the aim of capturing the island of Cyprus and realizing enosis, unification with motherland Greece, as one of the steps of their "Great Ideal", on July 15, 1974, with the support of the Colonel's junta in Greece, the Greeks had organized a coup in Cyprus and declared unilaterally "The Cyprus Hellenic Republic". "The Cyprus Hellenic Republic" had lost its validity and took its place in the dusty pages of history, after the intervention of Turkey, under Article 4 of Addendum 1 of "Guarantees and Treaty of Alliance" in accordance with international law, who was one of the Guarantor powers of Republic of Cyprus, declared on August 16, 1960. After this intervention two different administrations, Greek Cypriot Administration and Turkish Cypriot Administration were formed on the island. Greek Cypriots have since adopted a strategy that seeks to take over the entire island, including its Exclusive Economic Zone. The Greek Cypriots and Greeks, who could not realize the unification of Cyprus with Greece according to the Megali Idea "Great ideal" which was declared in 1796, after the intervention of Turkey, in accordance with international law in July 20, 1974, have begun attempts to remove the relevant item in the Constitution of the Republic of Cyprus, to avoid the intervention of Turkey again in their next attempt to capture and dominate the Cyprus island. In addition to their attempts to avoid the intervention of Turkey in the future, the Greeks had determined the strategy to give permission to some of the member states of European Union to use their naval and air ports whenever they needed, to guarantee their military support, if one day they are forced to enter into armed conflict with Turkey. For this reason, some of the member countries of European Union and some others have the right to use military facilities or existing air and sea ports within the borders of Greek Cypriot Administration (GCA). As a result, it turns out that the Turkish Cypriots need to take counter measures in spite of the attempts of Greek Cypriots and Greece to take over the whole island. One of these measures is the military alliance agreement to be signed by Turkey, who for the time being possesses one of the most powerful armies of the region, and Turkish Republic Northern Cyprus (TRNC) allowing building a military air and naval base with in their territories. This article has been prepared for the purpose of better investigation and evaluation of this subject. The conclusion of this article puts forward the everlasting will of Greek Cypriots to get hold of the Cyprus island and government in full, The Turkish Cypriots and Turkey's deliberate opposition to this will and their efforts to block it, the international political crisis originated from the hydrocarbon resources in the Eastern Mediterranean, and the strategies of USA, EU and Russia to have some legal rights directly or indirectly on the regional energy resources. 
Keywords

Cyprus, GCA, TRNC, Turkish Cypriot, Greek Cypriot

\section{Introduction}

After the Second World War, after the pressure of the USA to European countries to stop fighting with each other and to give freedom to its colonies, Britain decided to give independence to the colony of Cyprus. On December 1958, at the NATO Foreign Ministers meeting in Paris, for the first time UK, Turkey and Greece Foreign Ministers have talked informally on the issue of granting independence to Cyprus. They came together again in Zurich on February 11, 1959 and have formed the Constitution of the proposed Republic of Cyprus. To the third and final meeting held on February 19, 1959 in London, the Prime Ministers of UK, Turkey and Greece, the Greek and Turkish Cypriot community leaders participated. In this meeting, the Constitution of the Republic of Cyprus was unanimously approved by the relevant parties and signed.

In Cyprus, the British colonial period ended and the Republic of Cyprus was proclaimed on 16 August 1960, with the Turkish Cypriots and Greek Cypriots to be the founders of the Republic (Faustmann, 2010). This state, which was actually a federation with its own rules, was destroyed on the 21st of December 1963 after the armed attacks Greek Cypriots to Turkish Cypriots with the desire to dominate the state and the island as a whole (Charalambous, 2013). In June 1964, the President of the Republic of Cyprus, Makarios III, declared the Doctrine of Necessity and amended the 13 articles in the Constitution, giving Turkish Cypriots the equal rights of partnership, unilaterally by the votes of only Greek MPs. Turkey, as the guarantor of the Republic of Cyprus, did not recognize diplomatically these amendments in the Constitution, called off the diplomatic relations with Makarios Government and addressed the new formation as "Greek Cypriot Administration" (GCA).

The inter-communal conflicts that began in 1963 lasted 10.5 years. On 15 July 1974 Greece attempted to impose a coup on the island. Turkey, as one of the guarantor states, intervened on July 20, 1974 to reestablish the 1960 Republic of Cyprus using the rights enshrined in the Constitution with the aim to prevent annexation of the island with Greece. After this intervention, the Greek Cypriots gathered in the southern part of the island and formed the Greek Cypriot Administration (GCA), while the Turkish Cypriots gathered in the northern part of the island and formed the Turkish Republic of Northern Cyprus (TRNC). In 2019, the population of the Greek Cypriot Administration was 854,800 (Country Information, 2018) and the population of the Turkish Republic of Northern Cyprus was 374,299 (Baybars, 2019) (Figure 1).

\section{Military Bases in Cyprus}

There is a British military base called "British Sovereign Bases" in the Akrotiri 


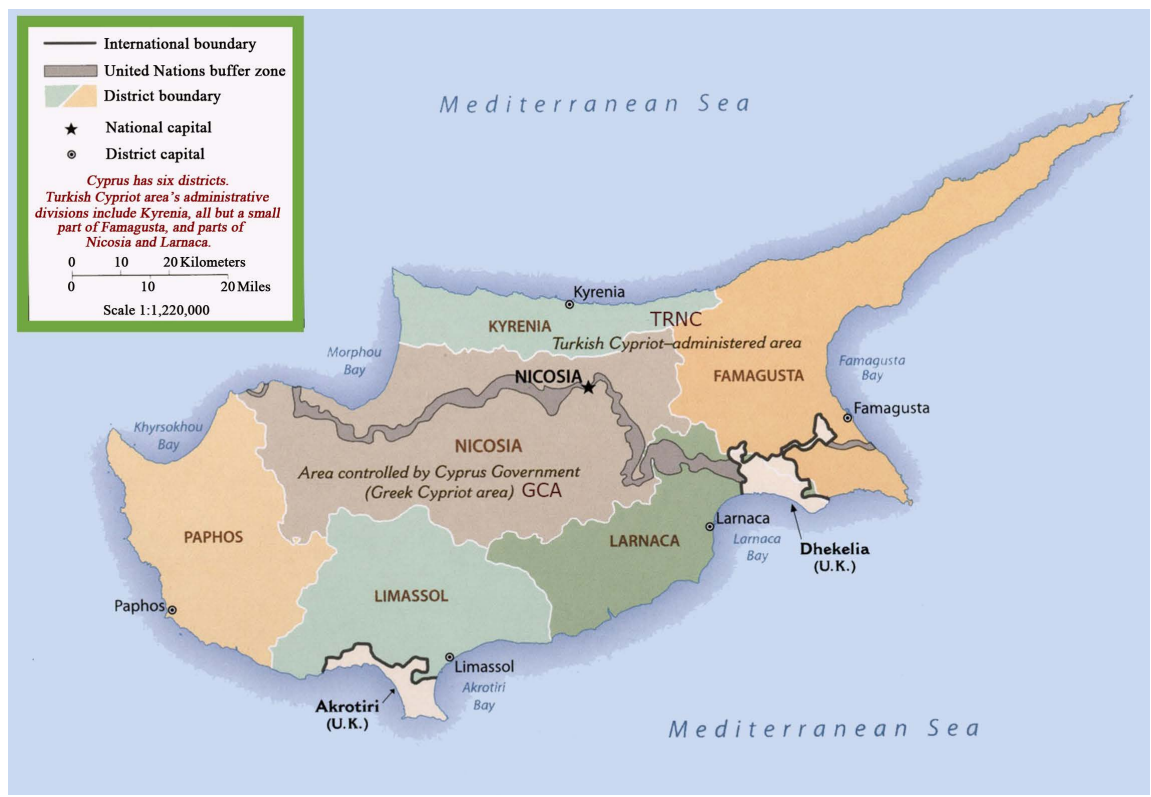

Figure 1. Map of Cyprus. Retrieved on May 8, 2019 from:

http://ontheworldmap.com/cyprus/cyprus-political-map.html.

and Dikelya regions as a result of the Zurich-London Agreements in 1959 and as defined in the 1960 Constitution of the Republic of Cyprus (Constitution of the Republic of Cyprus, 1960).

These sovereign bases, which are considered to be British territory, have their own sea ports, airport, nuclear weapons depots, FIR emission line and postal service (Loucaides, 2017). Moreover, the British sovereign bases of Akrotiri and Dikelya provide NATO with the largest electronic and signal intelligence throughout the region. Although not included in the 1960 Constitution, in accordance with the Law of the Sea adopted in 1982, it is claimed that the bases has their own exclusive economic zones, and therefore have rights to this end.

\section{Military Agreements of the GCA with Other Countries}

\subsection{GCA-Greece Joint Defense Doctrine (1993)}

In 1993 the Greek Cypriot Administration signed an agreement regarding defense and military cooperation with Greece under the title of the "Joint Defense Doctrine" (Cyprus Armed Forces, 1997).

"Joint Defense Doctrine" agreement comprised of planning the joint military strategies and operations between the two countries; to held joint maneuvers, to reorganize the defense infrastructures of Crete, the Dodecanese Islands and Cyprus; To enable Greece to establish air and sea bases in Southern Cyprus and allowing Greece to play a concrete role in the Mid Mediterranean; establishing a reliable telecommunications system; Improving the education of Greek Cypriots and increasing military expenditures. With the "Single defense area" concept defined by this new strategic concept, the region extending from Greece to the Fa- 
magusta in the island is considered as a natural defense area and it is aimed to ensure efficiency in every corner of this region. Within the framework of the aforementioned doctrine, the Pafos Military Airport was built, and the S-300 missiles were purchased from Russia in addition to the construction of the Mari Naval Base (Cyprus Armed Forces, 1997).

\subsection{GCA-Russian Federation Special Agreement (2015)}

In the same context, in 2015 (Holodony, 2015) and 2017 the Russian Federation made a special agreement with the Greek Cypriot Administration (GCA) to use the Lieutenant Evangelos Florakis naval base in Mari (Tatlısu) and Andreas Papandreu Airport in Paphos as well (BBC, 2015).

\subsection{GCA-France Special Agreement (2006)}

France, and therefore indirectly the European Union (EU), made a special agreement with the Greek Cypriot Administration in 2006 to use the naval bases of Lieutenant Evangelos Florakis naval base and Andreas Papandreu Airport (Hazou, 2019). It is also to be recalled that the French Navy had used Lieutenant Evangelos Florakis naval base 40 times in 2016 (Christou, 2017).

\subsection{GCA-Israel Special Agreement (1985)}

Furthermore, the Greek Cypriot Administration signed an agreement with Israel to grant control of a specific area of the port of Limassol used for cruise ships and ferries to start up the Limassol-Haifa services in 1985. Indeed, the Mavi Marmara incident in 2011 between Turkey and Israel saw the level of diplomatic relations reduced to an all-time low between the two countries (UN, 2011). The Greek Cypriot Administration implemented the "enemy of my enemy is my friend" principle and signed a deal with the Israeli military to conduct searchand-rescue and other naval exercises.

\section{Military and Political Initiatives in Eastern Mediterranean Region}

The latest developments regarding the United States in the Middle East is also interesting. The USA Incirlik Military Base in Turkey has now been subject to supervision and control by the Turkish authorities after signing official military sea, land and air base agreements with Israel, followed by talks with the Greek Cypriot administration to set up air and sea bases (Zacharova, 2018).

On the other hand, especially in recent years the Greek Cypriot leadership has taken deliberate steps to minimize the level of Turkey's relations with the EU and NATO. As a result, decisions taken at the November 14, 2017, Summit held in Brussels has been very encouraging for the Greek Cypriot Administration (EU Council, 2017).

In said Brussels Summit, Turkey's objection to the Greek Cypriot Administration's claims to control the Exclusive Economic Zones throughout the Eastern 
Mediterranean were not met with approval. Consequently, Turkey's own claims concerninig seismic surveys and drilling activities along with military activities were declared illegal.

In fact, the EU has constantly blamed Turkey for posing a threat to Southern Cyprus and harassing Greece in the Aegean. Furthermore, Turkey was invited to respect international law in order to normalize its relations with the EU. In the Brussels Summit, PESCO (Permanent Structured Cooperation Defense Agreement) green lighted seventeen projects adopted for the development of war preparation training programs, and six of them took place in the Greek Cypriot Administration (EU Council, 2017).

In particular, the "Military Mobility (Mobility)" and "Increasing the Marine reconnaissance and surveillance capabilities" projects are severely important to Turkey and the TRNC in military terms. In October 2017, the NEMESIS 2017 military exercise was carried out in the so-called Exclusive Economic Zone declared unilaterally by the Greek Cypriot Administration, France, Israel, Greece, Britain and the EU Maritime Security Agency (EMSA). It must not be overlooked that Turkey regarded this joint military exercise as an act of intimidation (Kokkinidis, 2017).

In the last six years, the Greek Cypriot Administration has developed their military cooperation developed with the US, the EU, Russia and Israel. Indeed, two lines of defense have been created: one with Israel in the Eastern Mediterranean and the other in the Western Mediterranean with the EU.

\section{Political Balance Changes in the Eastern Mediterranean}

The US, EU, Russia, Iran, Israel and Turkey have all been affected by a variety of reasons by the war in Syria since 2011. The ongoing internal conflict has shaken the balance in the region that had been laid forth according to the Law of the Sea Exclusive Economic Zone energy deposits identified in 1958 and 1960 I. and II. Sea Law Conferences. In addition, the Greek Cypriot Administration unilaterally declaring the Exclusive Economic Zone in the Mediterranean energy-bed, has been seen as an act to destroy the rights of Turkey and Turkish Cypriots. If this is not possible, then the Greek Administration will at least take initiatives to restrict them (Russell, 2018).

Balances have changed in the region. Taking into account Turkey being the East Mediterranean's most strategic country with the Middle Eastern mainland only $80 \mathrm{~km}$ away, neighboring with the South east of Israel, and Syria in the north east, it is crucial that Turkey establishes air and land-sea bases on the Turkish Cypriot side of the island. Actually, the TRNC and Turkey should have immediately taken precaution as soon as Greece and the Greek Cypriot Administration had signed a Joint Defense Doctrine in 1998 (Andreu, 2018).

The Greece-based coup on 15 July, 1974, declared the "Cyprus Helenic Republic" and the "Republic of Cyprus" was destroyed. The Turkish Cyprus Peace Forces (KTBK), which has set foot on the island in full compliance with international law, has been legally existing on the island ever since. In the same 
way, the Turkish Cypriot Regiment "has been deployed on the island in accordance with the" Alliance Agreement" in the 1960 Constitution of the Republic of Cyprus (Cool, 2014).

Clearly, the political and military balances in the region and in the world have changed dramatically since 1960. In particular, the form of government on the island of Cyprus has changed with the establishment of two separate states. It appears that the Greek Cypriot Administration has relied on the EU support in their piratical schemes to unilaterally declare the Exclusive Economic Zone solely under their domination. With the seven-year conflict in Syria posing a very real threat in the region, it has become obligatory that Turkey establishes a modern and fully-equipped land, air and naval base on the Turkish side of $\mathrm{Cy}$ prus that can handle all kinds of logistical support and look after the Turkish interests within the Exclusive Economic Zone. More to point, Turkey should sign a military agreement with the TRNC, similar to the USA-Israeli Bases agreement. According to the 1960 Republic of Cyprus Constitution, the Turkish Armed Forces (TSK) is legally stationed on the island and diplomatically does not recognize the Greek Cypriot Administration (CY Constitution, 1960).

\section{Turkey-TRNC Collaboration}

On the other hand, on September 21, 2011, during United Nations assembly in New York, Turkish Prime Minister Recep Tayyip Erdogan and President Dervis Eroglu of TRNC signed the "Turkey-TRNC Continental Delimitation Agreement." This agreement between Turkey and the TRNC was determined by 27 geographical coordinates in accordance with international law (Eler, 2014).

After this agreement, the TRNC Energy Ministry authorized TPAO to conduct research in its Exclusive Economic Zone. Similarly, the TRNC and the Republic of Turkey made an official agreement on air, land and sea defense. As a continuation of this agreement, the TRNC should allocate a location suitable for a Turkish military base.

Geçitkale Airport, which was built in the early 1980s, due to it's development potential, favorable meteorological conditions and its location being away from the border, could be the part of the Turkish Military base as it's runway is longer than the Ercan Airport's.

At present, the Navy linked with the Turkish Armed Forces is using a relatively small building in limited surroundings at the eastern port of Famagusta, as its headquarters.

In order to be able to intervene in any activity in the Eastern Mediterranean in the shortest response time, the local Navy and the Navy of the Turkish Armed Forces must be deployed at the former RMMO Naval Base in the Iskele area. In order to intervene in any activity in the sea area between Turkey and TRNC and receive logistical support within the shortest period of time, Gemikonağ located in the northern coast of TRNC may be appropriate to establish a naval base.

Indeed, it is extremely important that the deployment of soldiers and the establishing of these bases are done in accordance with legal agreements between 
Turkey and TRNC. Such official agreements will be a very correct political and military step in the overall situation in the Middle East as well.

\section{The Objections of the Greek Cypriot Administration}

The objections coming from the Greek Cypriot side to establish a military base in the TRNC should be ignored by Turkey. It needs to be taken into account that till this day steps taken by Turkey to please the Greek Cypriots caused a lot of mistakes.

The military base of TRNC and Turkey to be established in the TRNC will be a political and military advantage. In the past, and currently, the Greek Cypriot Administration has made military cooperation and base agreements with the US, the EU and EU countries, Russia and Israel without even consulting with or paying any heed to the opinions of Turkey and the TRNC. This means that the Greek Cypriot Administration is not very much bothered by the reactions of the EU (despite being an EU member), the US or the UK in terms of international reciprocity (ensuring equality in international relations) (Hayatsever, 2018).

Moreover, the Greek Cypriot Administration has declared the Exclusive Economic Zone is exclusive to them without feeling the need to consult with TRNC and Turkey at all. As a response, Turkey need not request permission from the Greek Cypriot Administration to establish a military base in TRNC, given that the Greek side has one-sidedly declared the entire island as EU land according to the 10th protocol (Presidency of the Turkish Republic of Northern Cyprus, 2003).

\section{Conclusion}

It is clear that the establishment of a full-fledged Turkish military base in the TRNC will have a positive impact on the resolution of the Cyprus problem. This base can be characterized as a deterrent to the idea of a possible attack on the TRNC, and as a force to provide military balances in the Eastern Mediterranean.

In the early hours of Saturday, December 21, 1963, in order to annul the 1960 Republic of Cyprus Constitution and to connect the island of Cyprus to Greece, the Turkish Cypriots, who made up a quarter of the population, were subject to assaults and killings. With the aim of eliminating these merciless attacks on the Turkish Cypriots, the Turkish military intervened on the island in 1974. Indeed, the Turkish military base to be established in TRNC will also play a deterrent role not to repeat these mass killings of Turkish Cypriots once again.

Considered a diplomatic genius, Fatin Rüştü Zorlu, Democratic Party Parliamanent Minister between the years 1950-1960 for the Republic of Turkey said when he was Deputy Prime Minister in 1955, "Cyprus has strategic importance for Turkey. In war Turkey can only look to sustenance by way of the southern ports. An enemy with the strength to dominate the islands in the Aegean Sea and the island of Cyprus at the same time spells a real siege for Turkey. No country can rely on another country on its security even if it is a friendly one." 
His words are still valid. It is necessary to take rational steps without forgetting this reality and the past of Cyprus.

The Military Base to be established in the TRNC will have a positive impact on the settlement of the Cyprus Problem.

\section{Conflicts of Interest}

The authors declare no conflicts of interest regarding the publication of this paper.

\section{References}

Andreu, E. (2018). Turkey Planning to Establish "Sovereign Base" in the North-Reports. Nicosia: Cyprus Mail Gazette, 28 August 2018.

Baybars, A. (2019). Baybars: KKTC nüfusu 374 bin 299. Lefkoşa: Diyalog Gazetesi Printing Office, Diyalog News Paper, 27 March 2019.

BBC (2015). Cyprus Signs Deal to Allow Russian Navy to Use Ports. Cymru: Wales.

Charalambous, L. (2013). Fifty Years Later, We Still Don't Accept What We Did in 1963. Cyprus Mail Gazette, 22 December 2013.

Christou, J. (2017). Cyprus-France Seen Upping Defence Ties. Nicosia: Cyprus Mail Gazette, 7 November 2017.

Constitution of the Republic of Cyprus (1960). http://www.parliament.cy/easyconsole.cfm/page/download/filename/SYNTAGMA_EN .pdf/foldername/articleFile/mime/pdf/

Cool, B. (2014). The 1974 Turkish Intervention. A Moment in U.S. Diplomatic History, Arlington: Association for Diplomatic Studies \& Training.

Country Information (2018). Country Information: Cyprus at a Glance. Nicosia: Country Profiler, 30 August 2018.

CY Constitution (1960). Constitution of the Republic of Cyprus. London: Presented to Parliament by the Secretary of State for the Colonies, the Secretary of State for Foreign Affairs and the Minister of Defence by Command of Her Majesty July 1960 CMND. http://www.kypros.org/Constitution/

Cyprus Armed Forces (1997). http://www.glavx.org/cyprus/cyarmy.htm

Eler, L. (2014). Annex to the Letter Dated 30 May 2014 from the Charge d'affaires a.i. of the Pernianent Mission of Turkev to the United Nations addressed to the Secretarv-General. New York: UN HQ, Sixty-Eight Session, Agenda Items 42 and 76.

EU Council (2017). Eastern Partnership Summit_Joint declaration. Brussels: EU HQ.

Faustmann, H. (2010). Independence Postponed: Cyprus 1959-1960 (pp. 229-246). Nicosia: University of Nicosia Press.

Hayatsever, H. (2018). Kıbrıs'a Türkiye üssünün kurulması için geç bile kalındı, bu adım Kıbrıs sorununun çözümüne de olumlu etki yapar. Sputnik, 28 August 2018.

https://sptnkne.ws/jxU9

Hazou, E. (2019). Naval Base Buzz Builds as French Ambassador Visits Mari. Nicosia: Cyprus Mail Gazette, 5 February 2019.

Holodony, E. (2015). Russia Reportedly Getting Military Bases in an EU State. Business Insider. New York: NY Tech Alliance.

Kokkinidis, T. (2017). Multinational Military Exercise Takes Place in Cyprus. Nicosia: Cyprus Mail Gazette, 17 October 2017. 
Loucaides, D. (2017). Why Are There Still British Military Bases in Cyprus? New Internationalist Annual Report 2017-2018. Oxford (UK): New Internationalist Publications Ltd.

Presidency of the Turkish Republic of Northern Cyprus (2003). Protocol 10 of the Accession Treaty 2003. Nicosia: Presidency of the Turkish Republic of Northern Cyprus. https://kktcb.org/en/documents-reports/eu-union/2003-protocol

Russell, M. (2018). Russia in the Middle East: From Sidelines to Centre Stage. Brussels: European Parliamentary Research Service (EPRS) PE 630.293, November 2018.

UN (2011). Report of the Secretary-General's Panel of Inquiry on the 31 May 2010 Flotilla Incident. New York: UN HQ, September 2011.

Zacharova, M. (2018). Reports of Planned US Military Involvement in Cyprus Persists. Nicosia: Cyprus Mail Gazette, 9 December 2018. 